ailments of the industry, but if integrated with other phases of a public relations program, they might bear unbelievably good dividends. There is everything to gain and nothing to lose. It is a chance worth taking.

\title{
General Meeting of the Business Historical Society
}

A general meeting of the Society will be held on April 11, 1946, at 10 A.M. in the Baker Library, Graduate School of Business Administration, Harvard University, Soldiers Field, Boston, Massachusetts. President John W. Higgins will preside.

Business :

Report of the Nominating Committee and Election of Officials of the Corporation.

Report of the Clerk on the Membership of the Society.

Report of the Treasurer on the Financial Condition of the Society.

Program :

General Subject for Discussion:

"Shift from Government Regulation to Government Control of Business."

Four brief papers will be read and then discussion will be thrown open to the floor.

Following the general meeting there will be a luncheon for the Council, to which all members of the Society and participants in the program are cordially invited. This luncheon will begin promptly at 12:30 at the Faculty Club of the School of Business. 